\title{
Choice of Low Cost Construction Technologies
}

\author{
Khanaliev G.I. \\ Grozny State Oil Technical University named after \\ academician M. D. Millionshchikov \\ Grozny, Russia \\ hgis@mail.ru
}

Istamulov A.M.

Grozny State Oil Technical University named after academician M. D. Millionshchikov

Grozny, Russia

apkarovia@mail.ru

\section{Aleroeva L.S.}

Grozny State Oil Technical University named after academician M. D. Millionshchikov

$$
\text { Grozny, Russia }
$$

liza.bonk.85@mail.ru

\author{
Aptaev Kh.Kh. \\ Grozny State Oil Technical University named after \\ academician M. D. Millionshchikov \\ Grozny, Russia \\ halid.aptaev@mail.ru
}

\author{
Magomadov I.Z. \\ Grozny State Oil Technical University named after \\ academician M. D. Millionshchikov \\ Grozny, Russia \\ magomadov.isa@bk.ru
}

\section{Mamatsuev R.A.}

Grozny State Oil Technical University named after academician M. D. Millionshchikov

Grozny, Russia

serbsul@gmail.ru

\section{Mallaev A.A.}

Grozny State Oil Technical University named after academician M. D. Millionshchikov

Grozny, Russia

adian.mamasurov@mail.ru

\section{Aysungurov N.D.}

Grozny State Oil Technical University named after academician M. D. Millionshchikov

$$
\begin{gathered}
\text { Grozny, Russia } \\
\text { aysungurov91@mail.ru }
\end{gathered}
$$

to the same sphere of application, but have different benefits due to different physical properties, chemical composition, and application technology.

The method of analytical hierarchy (further to be referred to as MAH) will be used to choose the best product $[1,2,3]$.

Among the most commonly used construction technologies the following were chosen for the analysis: superpave technology, soil stabilization, cold deep in-place recycling, cheap seal and slurry seal pavement technologies, 3D printed homes, housing from iron cargo containers, cardboard housing, rapid construction, trenchless pipe rehabilitation methods.

\section{Design Analysis Of The Chosen TeChNOLOGIES IN CONSTRUCTION}

Now it is possible to carry out the design analysis of the above-mentioned innovations from the perspective of their use for the development of construction industry in the Chechen Republic. Certain key parameters are traditionally used to design the model concepts, techniques, materials, etc. Let us define one key parameter for construction technologies - low cost, which includes: low labor input; resource-efficiency; profitability; low materials consumption. The main MAH principle centers around the hierarchical structuring of problems $[4,5,6]$. The calculation is made in tabular form thus 
identifying the superiority margin $n$ of the chosen alternatives. This means that the number $n$, equal 1 (Table 1), characterizes equal importance of the compared innovations. The number $n$ equal 3 - weak superiority, 5 - essential superiority, 7 considerable superiority, 9 - unconditional superiority. If the parameter $j$ in the table exceeds the parameter $i$, then one is divided by $n-1 / n$. Figure 1 shows the general hierarchical structure of the model of the choice of the best technologies.

Next, let us define the parameters critical for decisionmaking regarding the choice of the best elements. Then, let us define the weight values of the chosen key parameters for the studied innovations, make decision matrixes for the use of new technologies on the basis of the chosen key indicators, carry out pair-wise comparison of innovations in order to estimate the degree of their importance. Let us choose innovations according to their importance for construction [7, 8]. Using the above model of calculation via the method of analytical hierarchy, let us make the comparative analysis of the considered innovations against the above key indicator for further application in construction.

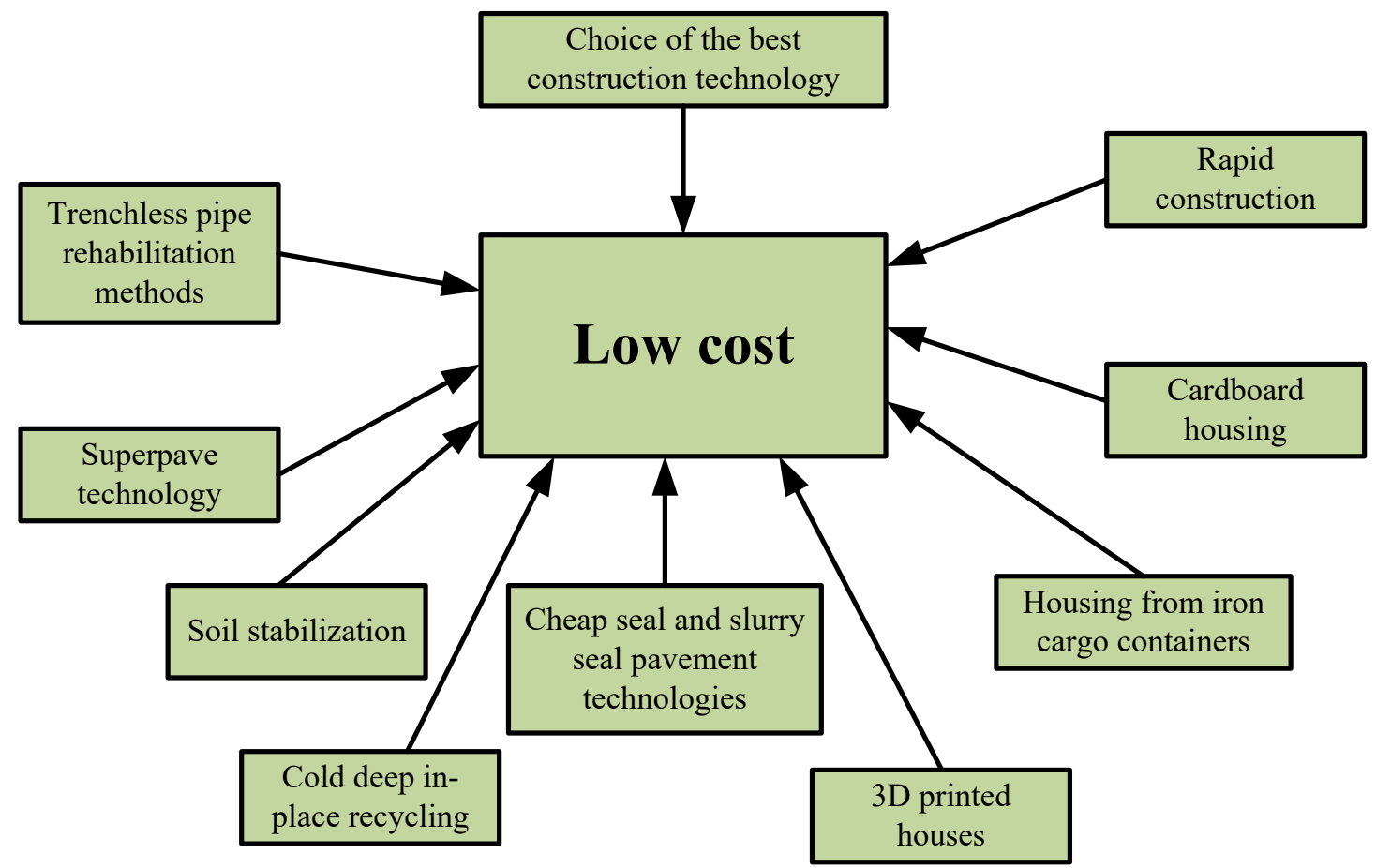

Fig. 1. Hierarchical structure of the choice of the best construction technology

TABLE I. PAIR-Wise Assessment OF Low Cost Construction TeChNOLOGiEs

\begin{tabular}{|c|c|c|c|c|c|c|c|c|c|}
\hline Low cost & 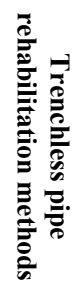 & 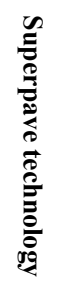 & 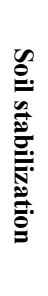 & 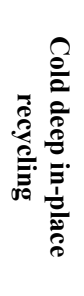 & 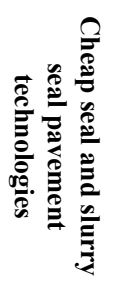 & 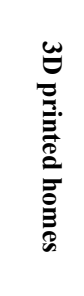 & 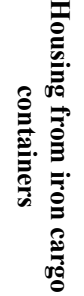 & 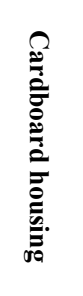 & 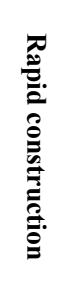 \\
\hline $\mathbf{i}$ & \multicolumn{9}{|c|}{$\mathbf{j}$} \\
\hline $\begin{array}{l}\text { Trenchless pipe rehabilitation } \\
\text { methods }\end{array}$ & 1 & 5 & 3 & 5 & 5 & 7 & 5 & 9 & 1 \\
\hline Superpave technology & 0.2 & 1 & 5 & 1 & 1 & 0.14 & 5 & 0.11 & 0.11 \\
\hline Soil stabilization & 0.14 & 0.2 & 1 & 0.2 & 0.2 & 0.14 & 0.2 & 1 & 0.11 \\
\hline Cold deep in-place recycling & 0.2 & 1 & 1 & 1 & 0.2 & 3 & 3 & 3 & 0.11 \\
\hline $\begin{array}{l}\text { Cheap seal and slurry seal pavement } \\
\text { technologies }\end{array}$ & 0.2 & 1 & 5 & 5 & 1 & 1 & 0.33 & 1 & 0.11 \\
\hline 3D printed homes & 0.14 & 7 & 7 & 0.33 & 1 & 1 & 5 & 1 & 0.11 \\
\hline Housing from iron cargo containers & 0.2 & 0.2 & 5 & 0.33 & 3 & 0.2 & 1 & 3 & 3 \\
\hline Cardboard housing & 0.11 & 9 & 1 & 0.33 & 1 & 1 & 0.33 & 1 & 3 \\
\hline Rapid construction & 1 & 9 & 9 & 9 & 9 & 9 & 0.33 & 0.33 & 1 \\
\hline Total & 3.19 & 33.4 & 37 & 22.19 & 21.4 & 22.48 & 20.19 & 19.44 & 8.55 \\
\hline
\end{tabular}


TABLE II. IMPORTANCE OF LOW COST CONSTRUCTION TECHNOLOGIES

\begin{tabular}{|c|c|c|c|c|c|c|c|c|c|c|c|}
\hline Low cost & 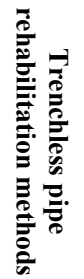 & 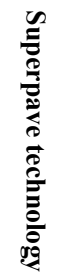 & 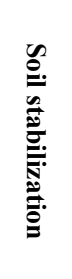 & 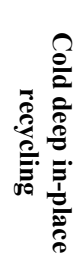 & 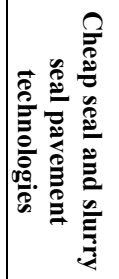 & 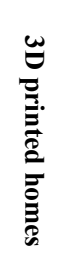 & 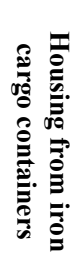 & 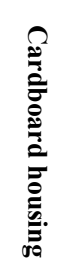 & 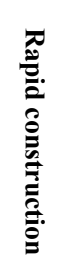 & 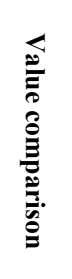 & 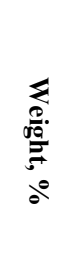 \\
\hline $\mathbf{i}$ & \multicolumn{11}{|c|}{$\mathbf{j}$} \\
\hline $\begin{array}{l}\text { Trenchless pipe rehabilitation methods } \\
\text { (T 1) }\end{array}$ & 0.31 & 0.15 & 0.08 & 0.23 & 0.23 & 0.31 & 0.25 & 0.46 & 0.12 & 0.46 & 17 \\
\hline Superpave technology (T 2) & 0.06 & 0.03 & 0.14 & 0.05 & 0.05 & 0.01 & 0.25 & 0.01 & 0.01 & 0.02 & 0.72 \\
\hline Soil stabilization (T 3) & 0.04 & 0.01 & 0.03 & 0.01 & 0.01 & 0.01 & 0.01 & 0.05 & 0.01 & 0.01 & 0.36 \\
\hline Cold deep in-place recycling (T 4) & 0.06 & 0.03 & 0.03 & 0.05 & 0.01 & 0.13 & 0.15 & 0.15 & 0.01 & 0.01 & 0.36 \\
\hline $\begin{array}{l}\text { Cheap seal and slurry seal pavement } \\
\text { technologies (T 5) }\end{array}$ & 0.06 & 0.03 & 0.14 & 0.23 & 0.05 & 0.04 & 0.02 & 0.05 & 0.01 & 0.01 & 0.36 \\
\hline 3D printed homes ( $\mathrm{T} 6$ ) & 0.04 & 0.21 & 0.19 & 0.01 & 0.05 & 0.04 & 0.25 & 0.05 & 0.01 & 0.01 & 0.36 \\
\hline $\begin{array}{l}\text { Housing from iron cargo containers ( } \mathrm{T} \\
\text { 7) }\end{array}$ & 0.06 & 0.01 & 0.14 & 0.01 & 0.14 & 0.01 & 0.05 & 0.15 & 0.35 & 0.22 & 8 \\
\hline Cardboard housing (T 8) & 0.03 & 0.27 & 0.03 & 0.01 & 0.05 & 0.04 & 0.02 & 0.05 & 0.35 & 0.3 & 11 \\
\hline $\begin{array}{l}\text { Rapid construction } \\
\text { (T 9) }\end{array}$ & 0.31 & 0.27 & 0.24 & 0.41 & 0.42 & 0.40 & 0.02 & 0.02 & 0.12 & 1.74 & 63 \\
\hline
\end{tabular}

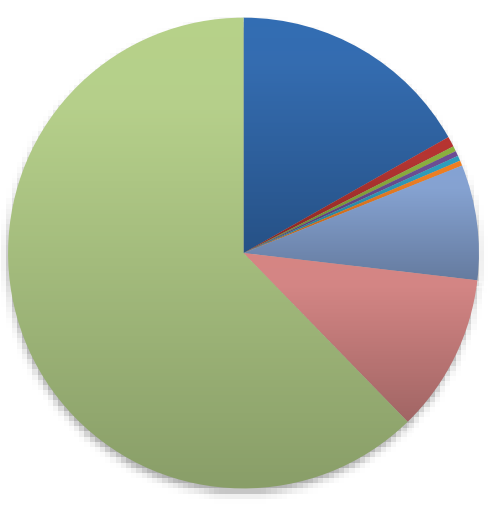

Fig. 2. Importance of low cost construction technologies, $\mathrm{T}-$ technology, 1, 2, 3-9 - technology number

\section{FINDINGS}

Following the results of the design analysis (Table 2, Figure 2) it is possible to conclude that such advanced construction technologies as trenchless pipe rehabilitation methods, housing from iron cargo containers, cardboard housing, and rapid construction are the most efficient and useful for introduction and application in the sphere of construction of the Chechen Republic [9, 10]. Besides, the most preferable of them are the ones having the highest weight values expressed as a percentage, $\%$ [11]. Thus: The rapid construction takes the first place - weight value equals $63 \%$;

The trenchless pipe rehabilitation methods take the second place - weight value equals $17 \%$;
Then, the cardboard housing - weight value equals $11 \%$;

And, finally, the housing from iron cargo containers weight value equals $8 \%$.

\section{CONCLUSIONS}

The above conclusions and literature facts make it possible to confirm that the advance of the trenchless pipe rehabilitation methods or other innovations of the construction industry may bring the maximum benefit from the perspective of the maximum economy of material and financial resources and will contribute to the development of the institutions involved into the studied field. The creation of special investment development coordination centers, development of methods and concepts on the introduction of highly efficient technologies, training of highly qualified staff will foster sustainable development of construction in the Chechen Republic. Besides, the above factors will also contribute to the progress in other spheres of human life and activities.

\section{References}

[1] A.Ya. Kibanovm Human resource management of the organization. Mocsow: INFRA-M, 2004, pp. 10-15, 34-36.

[2] D.A. Pustokhin, Materials management in intralogistic systems of production enterprises: thesis for a Cand. Sc. degree in Economics. Moscow: State University of Management, 2016.

[3] L.S. Aleroeva, "Innovations as a factor of urbanization and development of the Grozny city", Eurasia Science. Moscow: Aktualnost, 2017. [Collection of articles of the XII international scientific and practical conference, part II, 2017] 
[4] L.S. Aleroeva, "Role of innovations in housing and utilities infrastructure in the rational use of resources of the southern regions of Russia (on the example of the Chechen Republic)", January 15, 2018, Kazan. Ufa: AETERNA [International scientific practical conference onModern problems and tendencies of economy and management, p. 265, 2018]

[5] I.Z. Magomadov, P.A. Sidyakin, R.R. Palatov, "Protection of atmospheric air against dust during dismantling of buildings and constructions", Technology of civil safety, 2014, pp. 88-91.

[6] I.Z. Magomadov, "Ecological safety of reconstruction works, article on the Problem of industrial and environmental safety". Volgograd: VSUAC publishing house, pp. 60-63 [Collection of materials and articles of environmental engineers]
[7] G.I. Khanaliev, "Mechanism of balanced development of a transport complex", monograph. Stavropol: Fabula publishing information center, 2012, p. 227.

[8] A.D. Epstein, "Classification of innovations in housing and utilities infrastructure. Features of innovations in municipal and utilities infrastructure", Economic sciences, 2007, vol.27, No. 2, pp. 87-91.

[9] K.V. Krivov, "Problems of introduction of innovations into housing and utilities infrastructure", Naukovedenie. 2013, vol. 7. No. 6, pp. 1-9.

[10] D.S. Gorokhov, Construction innovations, retrieved from: http://www.expert74.com/74.

[11] V.A. Orlov, Restoration strategy of water and water collection systems Moscow: ASV, 2011, pp. 96. 